\title{
FIRST RECORD OF OILFISH, RUVETTUS PRETIOSUS (ACTINOPTERYGII, GEMPYLIDAE), OFF THE COAST OF BENGHAZI, LIBYA (SOUTHERN MEDITERRANEAN)
}

\author{
Houssein ELBARAASI*, Muftah ELMARIAMI, Moftah ELMEGHRABI, Salah OMAR \\ Department of Zoology, Faculty of Science, Garyounis University, Benghazi, Libya
}
Elbaraasi H., Elmariami M., Elmeghrabi M., Omar S. 2007. First record of oilfish, Ruvettus pretiosus (Actinoptery- gii, Gempylidae), off the coast of Benghazi, Libya (southern Mediterranean). Acta Ichthyol. Piscat. 37 (1): 67-69.

\begin{abstract}
The first record of oilfish, Ruvettus pretiosus Cocco, 1829, (Gempylidae) from the depth of $65 \mathrm{~m}$, caught off the coast of Benghazi, Libya (Southern Mediterranean), is reported herewith. The present finding appears to be an evidence of the extension in the latitude of its geographical distribution.
\end{abstract}

Keywords: fish, oilfish, Ruvettus pretiosus, first record, Mediterranean, Libya

The oilfish, Ruvettus pretiosus Cocco, 1829, is an oceanic, benthopelagic species, found world wide in tropical and warm temperate seas, generally living at depths between 100 and $700 \mathrm{~m}$ in the open ocean (Nakamura and Parin 1993). It lives in pairs or solitary and migrates far offshore (Anonymous 1994, Nakamura and Parin 2001, Maguire et al. 2006). It feeds on variety of fish, crustaceans, and squids. The flesh is very oily contains a strong purgative substance that may cause diarrhoea if too much is eaten (Nakamura and Parin 1993).

The occurrence of the oilfish in the Mediterranean basin was recorded by Kaya and Bilecenoğlu (1999) at the coast of Turkey. The species was also successively reported from the Italian coast at the Adriatic Sea (Bettoso and Dulčić 1999). In this short note, the first record of the oilfish, R. pretiosus, in Libyan waters is reported herewith.

The specimen of $R$. pretiosus was caught in March 2004, by a commercial bottom trawl, 7 nautical miles off the coast of Benghazi, southern Mediterranean, Libya $\left(32^{\circ} 06^{\prime} \mathrm{N}\right.$; $20^{\circ} 03^{\prime} \mathrm{E}$; Fig. 1), at the depth of approximately $65 \mathrm{~m}$. The fish was frozen on board by the fisherman. Once in the laboratory, the specimen was photographed (Fig. 2) and identified based on Nakamura and Parin (1993), and is now deposited in Natural Museum of the Zoology Department, Faculty of Science, Garyounis University, Benghazi, Libya. The main morphometric and meristic data are shown in Table 1.

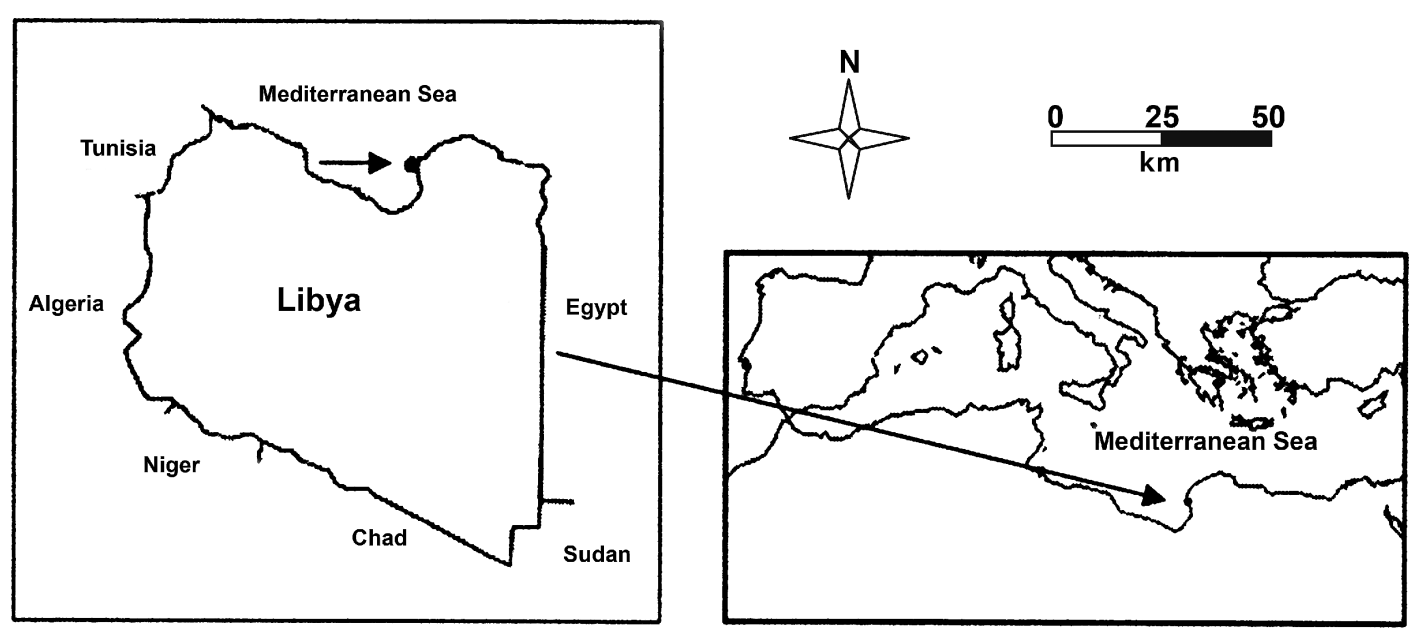

Fig. 1. Map showing where the herein reported specimen of Ruvettus pretiosus was collected off Benghazi, Libya

\footnotetext{
* Correspondence: Dr. Houssein Elbaraasi, Garyounis University, Faculty of Science, Department of Zoology, P.O. Box: 9480, Benghazi, Libya, phone: +21891379 4547, fax: +21861222 2805, e-mail: albrasi2000@yahoo.com
} 


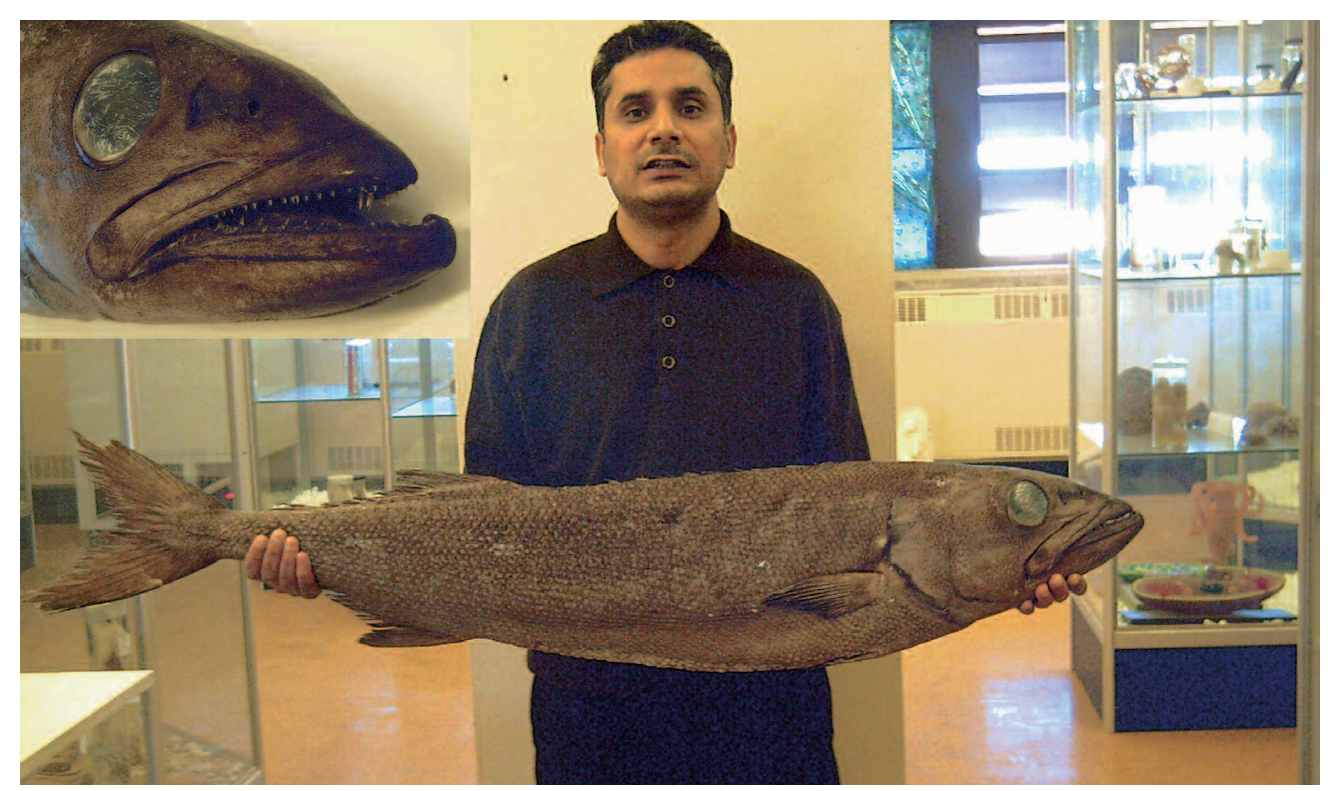

Fig. 2. The author, holding Ruvettus pretiosus; inset shows head of the specimen

Table 1.

Morphological and meristic data for the specimen of Ruvettus pretiosus caught in Libyan waters

\begin{tabular}{lcc}
\hline Morphometric data & Empirical value & $\begin{array}{c}\text { Relative value } \\
\text { [\% of total length] }\end{array}$ \\
\hline Total length [cm] & 131 & 100 \\
Standard length [cm] & 114 & 87.02 \\
Fork length [cm] & 123 & 93.89 \\
Anal length [cm] & 79 & 60.30 \\
Predorsal length [cm] & 31 & 23.66 \\
Head length [cm] & 34 & 25.95 \\
Maxillary length [cm] & 18 & 13.74 \\
Snout length [cm] & 13.5 & 10.30 \\
Eye diameter [cm] & 6 & 4.58 \\
Preorbital space [cm] & 9 & 6.87 \\
Dorsal fin base length [cm] & 71 & 54.19 \\
Anal fin base length [cm] & 23.5 & 17.93 \\
Pelvic fin length [cm] & 9.5 & 7.25 \\
Caudal fin length [cm] & 14 & 10.68 \\
Anal height [cm] & 19 & 14.50 \\
Body height [cm] & 24.5 & 18.70 \\
Total weight [g] & 16757 & \\
\hline Meristic data & & \\
\hline Dorsal fin rays & 15 & \\
Pelvic fin rays & IIII + 15 & \\
Pectoral fin rays & 5 & \\
Anal fin rays & 15 & \\
\hline
\end{tabular}

The specimen was $131 \mathrm{~cm}$ long (TL) and it weighed 16 basin (Dulčić and Grbec 2000, Dulčić et al. 2006). Thus, $757 \mathrm{~g}$. Body semifusiform, dark- brown with lighter sides and belly. Skin very rough, scales interspersed with spinous bony tubercles. Lower jaw extends slightly anterior to upper jaw. Sharp teeth present in both jaws; in addition to uniserial small teeth on vomer and palatines. Belly keeled by bony scales between pelvic fins and anus.

Over the last decade several investigators have reported the occurrence of new fish species in the Mediterranean the most likely possibility for the current finding is that arrived to Libyan coast by active migration or arrived as a refugee hidden inside fouling of a ship.

The finding of this species in Libyan waters is a new evidence of the extension in latitude of its geographical distribution. It could be also a sign of climate changes, and water warming. The occurrence of this species in depth of $65 \mathrm{~m}$ can be essential indicator of environmental changes. 


\section{ACKNOWLEDGEMENTS}

Many thanks are due to Mr. Salah Boshiba (Garyounis University, Benghazi, Libya) for his help. The authors wish to thank two anonymous reviewers for providing useful suggestions to improve the manuscript.

\section{REFERENCES}

Anonymous 1994. World review of highly migratory species and straddling stocks. FAO Fisheries Technical Paper 337. FAO, Rome.

Bettoso N., Dulčić J. 1999. First record of the oilfish Ruvettus pretiosus (Pisces: Gempylidae) in the northern Adriatic Sea. Journal of the Marine Biological Association of the United Kingdom 79: 1145-1146.

Dulčić J., Grbec B. 2000. Climate change and Adriatic ichthyofauna. Fisheries Oceanography 9: 187-191.

Dulčić J., Tutman P., Ćaleta M. 2006. Northernmost occurrence of the white grouper, Epinephelus aeneus (Perciformes: Serranidae), in the Mediterranean area. Acta Ichthyologica et Piscatoria 36: 73-75.

Kaya M., Bilecenoğlu M. 1999. Ruvettus pretiosus Cocco, 1829 (Teleostei: Gempylidae) — a new fish record for the Mediter- ranean coast of Turkey. Journal of Fisheries and Aquatic Science 16: 433-435.

Maguire J., Sissenwine M., Csirke J., Grainger R., Garcia S. 2006. The state of world highly migratory, straddling and other high seas fishery resources and associated species. FAO Fisheries Technical Paper 495. FAO, Rome.

Nakamura I., Parin N.V. 1993. Snake mackerels and cutlassfishes of the world (Families Gempylidae and Trichiuridae). An annotated and illustrated catalogue of the snake mackerels, snoeks, escolars, gemfises, sackfishes, domine, oilfish, culassfishes, scabbardfishes, hairtails, and frostfishes known to date. FAO species catalogue. Volume 15. FAO, Rome.

Nakamura I., Parin N.V. 2001. Gempylidae, Snakemackerels. Pp. 3698-3708. In: Carpenter K.E., Niem V. (eds.) The living marine resources of the western central Pacific. FAO species identification guide for fishery purposes. Volume 6. FAO, Rome.

Received: 1 March 2007

Accepted: 19 April 2007

Published electronically: 15 July 2007 